\title{
Asnād-e pāderiyān-e Karmelī bāzmānde az 'așr-e Šāh 'Abbās-e Șafavī / Remained Documents of Carmelite Padres Since Shah Abbas Era. Tehrān, Mīrāt-e maktūb, 1383/2004, 328 p., index.
}

\section{Jean Calmard}

\section{(2) OpenEdition}

\section{Journals}

Édition électronique

URL : http://journals.openedition.org/abstractairanica/18211

DOI : 10.4000/abstractairanica.18211

ISSN : 1961-960X

Éditeur :

CNRS (UMR 7528 Mondes iraniens et indiens), Éditions de l'IFRI

Édition imprimée

Date de publication : 15 mai 2007

ISSN : 0240-8910

\section{Référence électronique}

Jean Calmard, « Asnād-e pāderiyān-e Karmelī bāzmānde az 'așr-e Šāh 'Abbās-e Safavī / Remained Documents of Carmelite Padres Since Shah Abbas Era. Tehrān, Mìrāte maktūb, 1383/2004, 328 p., index. », Abstracta Iranica [En ligne], Volume 28 | 2007, document 204, mis en ligne le 18 septembre 2007, consulté le 25 septembre 2020. URL : http://journals.openedition.org/abstractairanica/18211 ; DOI : https://doi.org/10.4000/abstractairanica.18211

Ce document a été généré automatiquement le 25 septembre 2020.

Tous droits réservés 


\title{
Asnād-e pāderiyān-e Karmelī bāzmānde az 'aṣr-e Šāh 'Abbās-e Șafavī / Remained Documents of Carmelite Padres Since Shah Abbas Era. Tehrān, Mīrāte maktūb, 1383/2004, 328 p., index.
}

\author{
Jean Calmard
}

1 Cette édition de documents concernant les carmélites en Perse constitue un très important complément au travail de H. Chick, éd. (A Chronicle of the Carmelites in Persia..., 2 vols, Londres, 1939), aux documents concernant la correspondance de Šāh 'Abbās I ${ }^{\text {er }}$ avec les États européens édités par ‘Abd al-Ḥoseyn Navā’î (cf. Abs. Ir. 3, 1980, c.r. n 319), à la publication d'autres documents signalée par A. M. Piemontese dans son Catalogo dei manoscriti persiani... (Rome, 1989, cf. Abs. Ir. 14, 1991, c.r. n 17), p. 210, note 167, et aux contributions de Francis Richard (voir infra).

2 Le présent ouvrage concerne la publication de documents conservés à la Bibliothèque nationale de Naples. L'édition est basée sur la description donnée par A. M. Piemontese dans son catalogue (VI, Napoli, Biblioteca nazionale 235. Ms. III.F.30), reproduit en extrait (pp. 205-210 du texte italien, aux pp. 267-273 de cet ouvrage). Le manuscrit constitue l'unique copie traduite en persan de ces documents. Il est édité intégralement et présenté avec soin par M. Sotūde, décédé depuis. Il comporte 162 lettres envoyées d'Europe à la cour de Šāh 'Abbās et les réponses de la chancellerie de cette cour, ainsi que les farmān et dastūr du shah concernant, entre autres, le commerce de la soie. Dans une note (yād-dāšt), M. Afšār présente les sources et travaux et, notamment, outre le catalogue de M. Piemontese, les nombreuses contributions de F. Richard. Cette note est suivie d'un index (fehrest) présenté sous la forme d'un répertoire des intitulés des documents publiés, numérotés de 1 à 170 . Les noms propres européens sont signalés en 
caractères latins, entre crochets. Il est intéressant de noter que, dès l'intitulé de ce manuscrit persan, le Pape de Rome est nommé «Rim Pāpā » (Rim, en turc, pour le persan Rūm).

3 En annexes sont donnés: 1. La reproduction des première et dernière pages du manuscrit; 2. L'original italien de l'extrait du catalogue de A. M. Piemontese (voir supra) ; 3. La traduction persane, par M. RūḥbaHš̄ān, d'un article de F. Richard intitulé "Les privilèges accordés aux religieux catholiques par les Safavides, quelques documents inédits", paru dans Dabireh, $\mathrm{n}^{\circ} 6$ (Paris, automne 1989). L'ouvrage est complété par des index: noms de personnes; noms géographiques, des groupes tribaux, socio-religieux; mois du calendrier chrétien, suivis d'un tableau de concordance des dates hégirienne et chrétienne pour chacun des 170 documents. La réalisation soignée de cet ouvrage fait honneur à la collection Mīrāt-e maktūb.

INDEX

Thèmes : 4.2.1. Safavides et Qâjârs

\section{AUTEURS}

JEAN CALMARD

CNRS - Paris 